\title{
Effectiveness of Joint Venture for Local Contractors in a Mega Project Construction
}

\author{
Dagninet Cherinet \\ Department of Construction Technology and Management, College of Engineering and Technology, Wolkite University, Wolkite, Ethiopia \\ Email address: \\ Dagninetcherinet24@gmail.com

\section{To cite this article:} \\ Dagninet Cherinet. Effectiveness of Joint Venture for Local Contractors in a Mega Project Construction. American Journal of Civil \\ Engineering. Vol. 8, No. 4, 2020, pp. 97-105. doi: 10.11648/j.ajce.20200804.13
}

Received: August 4, 2020; Accepted: August 25, 2020; Published: September 14, 2020

\begin{abstract}
Mega Construction Projects are defined as a very large investment construction project, or aggregate of projects, characterized by magnified cost, extreme complexity, increased risk, lofty ideals, and high visibility, in a combination that represents a significant challenge to the stakeholders, a significant impact to the community and pushes the limit of construction experience. The main objective of this study was to assess effectiveness of joint venture for local contractor to construct a mega project construction. The specific objective of this study was to determine the effective way of formation and implementation procedure, to determine legal procedures and steps of joint venture between local contractors, to analyze different kinds of joint venture among local contractors and to analyze risk of joint venture among local contractors to construct a mega project construction. The study used both qualitative and quantitative research, and data collection method used was interview, close ended questionnaires', different books, articles, and web sites. The study uses also purposive sampling technique. The study revealed that the most motivation factor and reason to form a Joint Venture in construction is to obtain technology transfer, the most selection criteria to select a construction JV partner is ability, experience and skills of JV partner and to succeed in JV performance a JV management should be strong. The study indicated that some of the articles form the commercial code explains about JV need an amendment. The study also indicates legal issues should be considering in Ethiopian commercial code to facilitate formation construction JV. This study also revealed the best JV type suitable for local contractors to establish domestic $\mathrm{JV}$ is a contractual JV type. Finally, the study shows that the most factors to create a problem in construction JV is unclear partner roles and the dominant risk factor associated with construction JV is partner parent company in financial problem. Also, the study came up with conclusion that the existing legal norm context about CJV should be revised with amendment of some of the articles from the existing commercial code of Ethiopia.
\end{abstract}

Keywords: Joint Venture, Construction Joint Venture, Domestic Construction Joint Venture

\section{Introduction}

In Ethiopia the sector has registered a remarkable growth, over the last 11 years there has been increased investment on the development and expansion of various infrastructure projects. Among the major development's construction of road infrastructure, real estate developments, and condominium housing projects are some of the examples. More specifically public infrastructure development projects by ministry of Education and Health and road infrastructure projects accounts the significant portion of the investment outlay on construction activities [15].

Brockmann et. al, [3] also describes Mega projects are invariably described by using superlatives (the prefix "mega" is already one of them). One of the most recent mega project constructions in Ethiopia is Ethiopian Grand Renaissance Dam, Gilgel Gibe I, II, III, Ashegoga Wind Power Project and etc.

The Ethiopian Ministry of Urban Development and Construction [15]) states that promote meaningful joint ventures and other forms of strategic alliances with foreign partners to ensure effective participation of local players in construction projects. 


\section{Literature Review}

\subsection{Defining a "Mega Project Construction"}

Capka [5] states about one of the most widely accepted definitions is that given by the US Department of Transportation: a mega-project is a project with at least a USD 1 Billion budget. The US Federal Highway Administration (FHA) later gave a detailed definition of mega-projects:

"Projects of a significant cost that attract a high level of public attention or political interest. Because, of substantial direct and indirect impacts on the community, environment, and state budgets".

Mega-projects are interesting objects of study for two reasons. On the one hand, they are the most complex undertakings not only in construction but in all economic sectors. They extend the boundaries of our knowledge. On the other hand, they work like magnifying glasses; they unveil problems that might remain unnoticed on smaller projects [3].

MCPs are defined as a very large investment construction project, or aggregate of projects, characterized by magnified cost, extreme complexity, increased risk, lofty ideals, and high visibility, in a combination that represents a significant challenge to the stakeholders, a significant impact to the community and pushes the limit of construction experience [1].

In Ethiopia, one construction project is to be considering as a mega construction project is depending on construction type. Mega construction project should be including the following construction project type such as Infrastructure, Energy and Manufacturing industry. Some the most recent mega project constructions in Ethiopia are Ethiopian Grand Renaissance Dam, Gilgel Gibe I, II, III projects, Adama Wind Power Project and etc. [14]

\subsection{Defining a "Joint Venture"}

Bryan A. [4] in Black's Law Dictionary define a Joint Venture as a business undertaking by two or more persons engaged in a single defined project. In a similar fashion, Deborah E. [7] Joint Venture is also defined as an association of two or more persons or entities who combine their property skill, or knowledge to carry out a single enterprise for profit. In Ethiopian commercial code [6] define a joint venture as an agreement between partners on terms mutually agreed and is subject to the general principles of a law relating to partnership.

Contemporary literatures on Joint Venture tend to define 'Joint Venture' in terms of 'purpose' rather than in terms of 'a type of entity'. There are a lot of sources which hold the position that the term Joint Venture' refers to the purpose of the entity and not to a type of entity. The fact that joint venture is to be made for a single defined project or for a specific purpose is an emphasized element in many of the above definitions, indirectly supporting that joint venture is better described in terms of purpose rather than in terms of a type of business organization. Joint venture is a venture in which the ventures agree to share profits and losses can also be deducted from the above selected definitions [17]. Samuel A. [17] states that all the above disparities in the definition of Joint Venture, there may be a consensus that Joint Venture is:

A collaboration between two or more persons through an agreement in any form for a purpose of:

a. To pool their capital and resources together;

b. To jointly manage their business;

c. For a specific or defined purpose; and

d. To share costs and profits.

\subsection{General Back Ground of Joint Venture in Construction}

Hong Y. et al. [9] define a joint venture the appropriate definition of joint-venture groupings, in the context of the construction industry as:

"a business alliance of limited duration formed by two or more unrelated business or professional entities for the purpose of furnishing engineering, consulting, procurement, construction and construction management services by consolidating the skills and resources of the participants".

Depending on Minja et. al [13] states construction businesses are becoming more competitive due to complexity of client's requirements and technology advancement. Construction organizations are forced to form alliances at varying levels in order to stay in business. Some of the reasons dictating such alliances include surfacing of large and complex projects; pooling of resources; sharing of risks; entry to foreign market; access to technological improvements; political or diplomatic improvements. By pooling resources and complementary strengths, companies can increase productivity and competitive standing in ways they could not do by themselves.

\subsection{Implementation Procedure for Successful Construction Joint Venture}

\subsubsection{Steps in Formation of Joint Venture}

Zirape L. et. al. [21] states steps to formation joint venture

a. Planning

b. Partner selection

c. Feasibility study

d. Incorporation

\subsubsection{Reason for Formation of Joint Venture}

Ms. Kale, V. et. al [16] explain about reason for formation of joint venture in practice, some of these reasons are as follows:
a. Technology transfer
b. Sharing of political risks
c. Sharing of commercial risks
d. Competition strategy
e. Tax implications
f. Transaction cost approach
g. Resource dependency-Organization theory approach

\subsubsection{Success Criteria of JV}

Stewart M. et. al [18] also indicated Preliminary and definitive agreements for successful construction joint venture
a. Management

b. Governance 
c. Relative Contributions of Partners

d. Allocation of Risks and Rewards

e. Alternative Dispute Resolution Provisions and Deadlock Provisions etc.

\subsubsection{Selection Criteria for JV Partner}

Minja et al. [13] explains that prior to selection of a joint venture partner firms aspiring to form joint ventures should formulate or adopt criteria that will guide their undertakings. The main criteria considered when an organization is looking for possible partners to go into joint venture partnership are as follows

Ability, experience and skills: Require organization with proven ability experience and skills

Financial stability: Financial suitability is an important requirement for joint venture partnership

Similar business philosophy and concepts: This factor constitutes a basis for building a cohesive team with common goals.

Strength of partner's willingness to form joint ventures: The joint venture must be driven by both parties.

Spoken language: Most contractors prefer to look for partners abroad who speak the same language to avoid communication problems

\subsection{Legal Procedures of JV}

\subsubsection{Legal Frameworks and Practices of "Joint Ventures" in Ethiopia}

Joint venture under Ethiopian law can be said to be found under three separate legal frameworks; namely, the 1960 Commercial Code, the Investment Proclamation no.280/2002 and the Public Enterprises Privatization Proclamation no. 146/1991 (with its amendment Proclamation no. 182/1992). These legal frameworks do provide different types of "joint ventures" and thus we will explore these legal frameworks herein under.

\subsubsection{Joint Venture in Ethiopian Commercial Code}

Samuel A. [17] examined despite the fact that Joint Venture is considered as a business organization under Ethiopian law, we can however see that Joint Venture in Ethiopia has the following basic legal features:

a. Secrecy: the joint venture should not be known to third parties;

b. Informality: no formal requirements for the validity of a joint venture formation, i.e. need not be in writing, no registration, or no publicity;

c. No legal personality of its own; and

d. No name of its own: partners deal with third parties in their own names.

\subsection{Risks of Construction Joint Ventures}

Ms. Kale, V. et. al [16] states about problems occurred in joint ventures such are:

Unclear partner roles: A lack of clarity about how closely the two sides intend to work together is a common problem.

Unequal sharing of risks and benefits: An important issue to resolve before finalizing any deal is how the value generated by the venture will be distributed between the parents.

The inevitable crisis: If a joint venture gets off to a successful start, it will settle into a normal pattern of operation and stable relationships.

No exit mechanisms: When conflicts escalate beyond a certain threshold and the parties no longer feel they can work with each other; it is vital to have a formal exit mechanism in place so that costly and time-consuming litigation can be avoided.

Inadequate training: Inadequate $\mathrm{JV}$ training is an obstacle to implementing joint venture. Inadequate staff training is the essential reason for JV failure; the participants do not fully understand the concept of $\mathrm{JV}$ and hence are not able to implement partnering successfully.

Misunderstanding of partnering concept: A thorough knowledge and understanding of the JV process is essential to create partnering success; misunderstanding the JV concept is thus a major problem for partnering implementation.

\section{Research Methodology}

\subsection{Study Area}

The study was conducted in Addis Ababa, headquarters of Ethiopia. Addis Ababa was selected because almost all contractors registered on under F. D. R. E. Ministry of Urban Development and Construction is located in Addis Ababa.

\subsection{Study Design}

The design for this study was aimed to examine effectiveness of JV among local contractors in a mega project construction. This research study was following both qualitative and quantitative research approaches. For this research, an interview and questioner were used as a primary data for research data source. This research was using close-ended questionnaire type. Different published books, journals, records and different websites was used as a secondary data source for this study. Secondary data was used as supplementary source of information.

\subsection{Questionnaire}

The research was started with literature reviews. Based on the information acquired from literature reviews and input from various local experts, questionnaires were developed for survey exercise. Two types of questionnaires were developed for two diverse groups, construction organizations and public organizations.

The questionnaire designed for the construction organizations contained an overall of 162 questions in two sections. Section 1 consists of 9 questions and section 2 consists of 153 questions. The questionnaire prepared for public agencies and organizations were similar but they have to eligible to response only question 1 and 2 contained on section 1 . 


\subsection{Research Population}

Form 160 Grade - 1 building and general contractors registered in current year the targeted population of the study was grade 1 contractors with registered capital of greater than $60,000,000.00$ (Sixty Million) ETB, grade 1 consultants with registered capital of greater than 2,500,000.00 (Two and Half Million) ETB and public agencies and organization (MoUDC, MoTI etc.)

\subsection{Sampling Procedure}

The study was used purposive sampling to get sample size because these predefined groups help to attain this research objective. Purposive sampling is the one in which the person who is selecting the sample is who tries to make the sample representative, depending on his opinion or purpose, thus being the representation subjective (Barreiro and Albandoz, 2001).

\subsection{Data Analysis}

All the data collected on the effectiveness JV among local contractor in a mega project construction was organized \& analyzed by using excel software for making ranking priorities table and relevant answers was summarized in order to reach at meaningful conclusion.

To analyze the data for ranking purpose, have to be find a Mean Score (MS) value from the Likert Scale I was used the following formula

$$
\mathrm{MS}=\sum(\mathrm{f} \times \mathrm{x}) / \mathrm{N}
$$

Where;

a. $\mathrm{S}=$ score given to each cause of delay by the respondents;

b. $\mathrm{F}=$ frequency of responses to each score for each cause of delay;

c. $\mathrm{N}=$ total number of responses in the respective cause of delay.

After doing the analysis by using the above formula select the dominant factor with a Mean Score (MS) of greater than or equal to 3 by a means of ranking order.

\section{Discussion and Analysis}

\subsection{Response Rate}

A total of 141 completed questionnaires were returned from 180 for data analysis, 6 of which were administered through face-to-face interviews to construction stakeholders.

In this study 37 (63\%) grade I contractors have a capital of greater than 60,000,000.00 (Sixteen Million) ETB, 18 (37\%) consultant have a capital of greater than 2,500,000.00 (Two and Half Million) ETB and 5 (8\%) different government institution was participated in the questionnaire. The general response rate for grade I contractors and consultants described in the figure below.

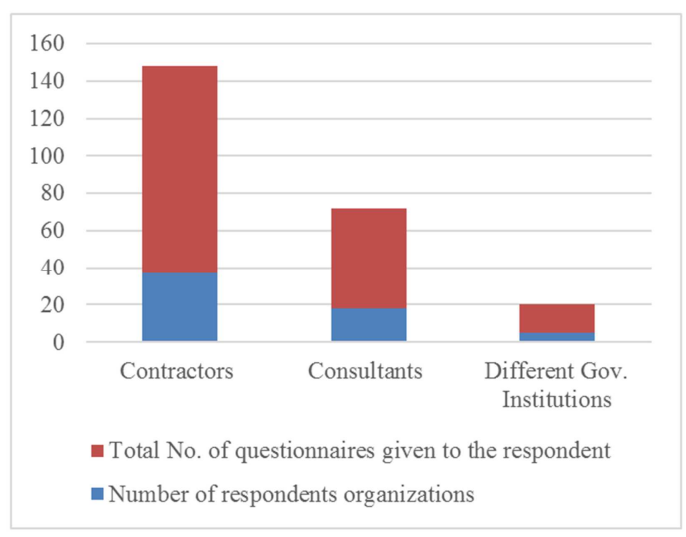

Figure 1. Distribution of questionnaire.

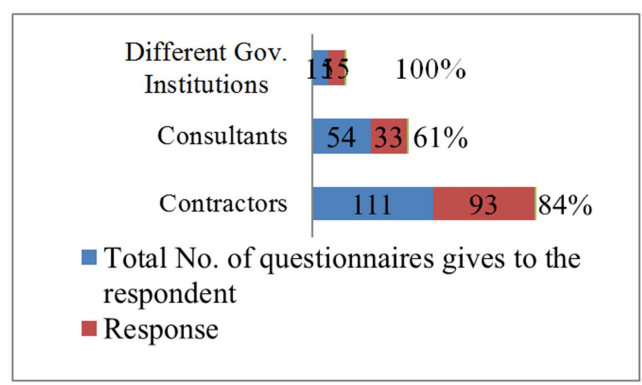

Figure 2. Distribution of response rate.

\subsection{General Information About Respondent}

\subsubsection{Concept of $J V$}

From the total respondent participated on the study $91 \%$ of the respondent have a concept about JV but $9 \%$ of the respondent doesn't have the concept about JV.

\subsubsection{Interest to form $\mathrm{JV}$}

Respondents have an interest to form a construction JV is (72\%), have no interest to form a construction JV is (28\%).

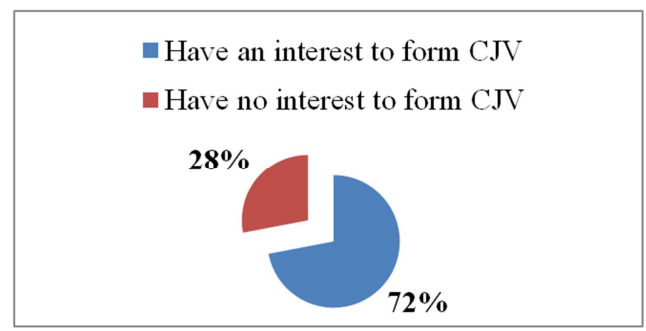

Figure 3. Respondents interest to form CJV.

From the respondents participated on this study $70 \%$ of the respondents prefer the foreign contractor to form JV the remaining $30 \%$ of the respondents prefer local contractors.

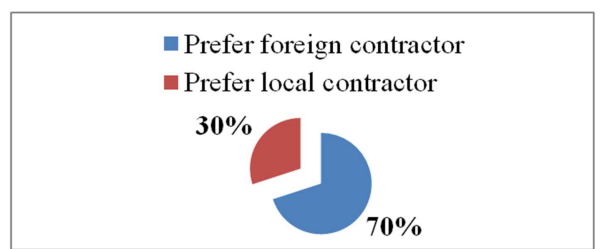

Figure 4. Respondents interest about nationality of contractor. $s$ 


\subsection{General Information About JV Projects}

\subsubsection{Construction Experience in Terms JV}

$44 \%$ of the respondent company has an experience in construction projects in terms of JV; $56 \%$ of the respondent company has no experience in terms of JV.

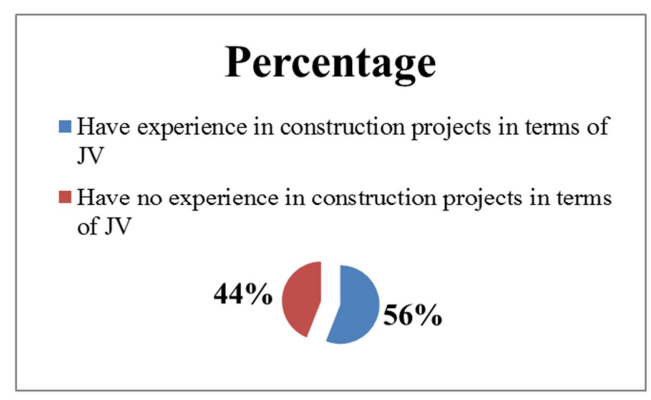

Figure 5. Respondents experience in construction projects in terms of CJV.

From JV experienced construction company table 1 show that the distribution of JV projects type. The dominant project type is building, followed by transportation and infrastructures.

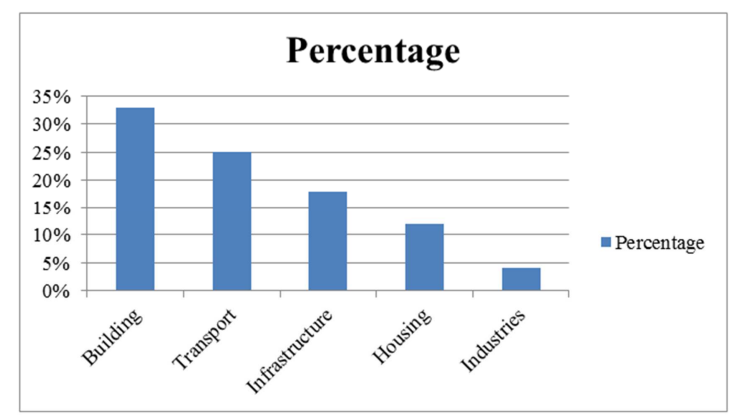

Figure 6. Dominant project type in terms of CJV.

\subsubsection{Contract Type}

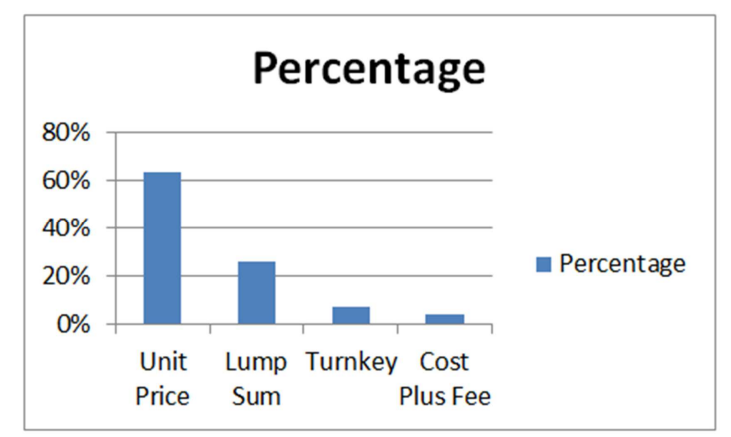

Figure 7. Contract type of JV.

\subsubsection{Disputes}

Only 2 contractors had some disputes with their partner whereas 25 contractors complete the JV without any dispute between the partners.

\subsection{Effective Way of JV Formation and Implementation Procedures}

This part consists of result and discussion of the effective way of JV formation and implementation procedures between local contractors. It includes the concepts of motivation factors and reason issues in establishing $\mathrm{JV}$, partner selection criteria and JV success criteria.

\subsubsection{Issues Related in Establishing JV}

The respondent ranked "Obtain technology transfer" in the first position with mean score (MS) of 4.18. This indicates to obtain a technology transfer is a reason to form a JV. Ms. Kale, V. et. al [16] also indicate obtain a technology transfer is the first reason to form a JV. The proper description of this agreement is to obtain a technology transfer has a high impact in establishing a JV.

The second important factor ranked by the respondent was "Make larger project feasible and possible" with a mean score of 4.01. This is strong indication that to make larger project feasible will to form a construction JV. This result coincides with the result of Minja et. al [13] and Hong Y. et. al [9]. The suitable description for this consensus is to execute or feasible a mega project construction a construction JV or alliance is the most important. The JV mode is suitable for large-scale engineering construction. So, to undertake large and complex construction project is the important factor to form the JV. "Making full use of idle resource" is ranked by the respondent as the third important factor to establish a JV with a mean score of 3.98. Minja et. al [13] and Hong Y. et. al [9] also coincides with the result of this research.

Table 1. Rank of factors for establishing JV.

\begin{tabular}{lll}
\hline Partner selection criteria factor & Mean Score & Rank \\
\hline Obtain Technology transfer & 4.18 & 1 \\
Make larger project feasible and possible & 4.01 & 2 \\
Making full use of idle resources & 3.98 & 3 \\
Learn management skills from your partner & 3.89 & 4 \\
Increase competition strategy & 3.89 & 5 \\
\hline
\end{tabular}

\subsubsection{Selection of Joint Venture Partner}

The respondent ranked "Ability, Experience and Skills" with a mean score of 4.20 as the first factor to select a JV partner. This indicates ability, experience and skills considered when a contractor is looking for possible partners to go into joint venture partnership. According to Minja et al. [13] result ability, experience and skills are the criteria to select JV partner. The proper argument for this agreement is ability, experience and skills are the important factor to select the JV partner.

The second factor to select the JV partner is "financial stability" with a mean score of 4.17. This implies financial stability of the partner has strong affect in selection of JV partner. Minja et al. [13] also agree with this result. The suitable description for this agreement is financial suitability is an important requirement for joint venture partnership" Minja et al. [13].

Third important factor ranked by the respondent is "Management skills" with a mean score of 4.01. This indicates high class management skills help to select by a JV partner. The suitable argument for this agreement is a good management skill is the important factor to select the JV partner. 
Table 2. Rank of JV partner selection factors.

\begin{tabular}{lll}
\hline Partner selection criteria factor & $\begin{array}{l}\text { Mean } \\
\text { Score }\end{array}$ & Rank \\
\hline Ability, Experience and Skills & 4.20 & 1 \\
Financial stability & 4.17 & 2 \\
Management skills & 4.01 & 3 \\
Understand own and shared risks & 4.00 & 4 \\
Strength of partner's willingness to form joint ventures & 3.96 & 5 \\
\hline
\end{tabular}

\subsubsection{Success Criteria of Joint Venture Performance}

The respondent ranked "management" in the first position with a mean score of 4.19. This indicates management of the Joint Venture is the most important factor to succeed in the formed construction JV. Stewart M. et. al [17] also agrees with this result by stating "It is critical that senior management be chosen early, be independent, have a clear charter and authority, and have clear reporting lines".

The following table shows that distribution of factor for successful construction JV the second dominant factor for successful JV is "trust among partners" with a mean score of 4.03 followed by "technical skills" with mean score of 4.03 and "handling the technical complexity" of the project with mean score of 4.01 .

Table 3. Factors of JV success.

\begin{tabular}{lll}
\hline Success Criteria & Mean Score & Rank \\
\hline Management & 4.11 & 1 \\
Trust among partners & 4.03 & 2 \\
Technical skills & 4.03 & 3 \\
Handling the quality requirements & 4.00 & 4 \\
Relative contribution of partners & 3.99 & 5 \\
\hline
\end{tabular}

\subsection{Legal Procedures of Joint Venture}

This part shows that the respondents believe "article272/4 of the commercial code" needs an amendment with mean score of 4.18. The respondents also believe "article 272/1 of the commercial code" need an amendment with mean score of 4.00. Article 2072/1 and Article 272/4 of the commercial code state about Article 272/1 about "JV should not be known to third parties and Article 272/4 about "a JV is known to be for third parties it shall be deemed to an actual partnership". This means the formed JV is secrecy and no name of its own (partners deal with third parties in their own names). This indicates from the Joint Venture partners only one of the parties has been authorized to represent the Joint Venture with any third parties. Those both Articles reduce the interest of local contractors to make a domestic Joint Venture. This kind of confidentiality makes a great doubt between JV partners. So, this result argues to create a strong inter-partner trust between JV partner Article 271/1 and 271/4 need to be amended.

"Article 272/3 and Article 272/2 of the commercial code" ranked by the respondents no need of amendment with mean score of 2.78 and 3.00 respectively. Article 272/1 states about legal personality of the JV, "A joint venture does not have legal' personality". Samuel A. (2010) state about the importance of legal personality in JV is "one major problem in such contractual 'joint venture' arrangement is the fact that the 'joint venture' has no legal personality of its own". The mean score of Article 272/3 shows by itself this article still now creates a big controversy between the construction stake holder and Ministry of Trade and Industry. When I was discussed with the Director of legal directorate of MoTI, He reinforced any kind of JV formed by any kinds of business organization doesn't have legal personality. Because, a JV is formed by two or more partners (company) those partners have their own legal personality due to this no need of additional legal personality for those JV partners. On the other hand, Samuel A. (2010) state about the importance of legal personality in JV is "one major problem in such contractual 'joint venture' arrangement is the fact that the 'joint venture' has no legal personality of its own". But this result describes Article 271/3 and Article 271/2 of the commercial code no need of amendment until the construction stake holder and MoTI reach on common consensus.

\subsubsection{Legal Issues to Be Consider in Commercial Code}

The first legal issues to be consider "duties and liability of partners" ranked by the respondents with mean score of 4.01 . Samuel A. [17] describe about liability of partners should be consider in commercial code in this statement "the liability of the partners to third parties is only subject to their direct involvement and dealings with third parties". This result helps to avoid full responsibility and unlimited liability of the partner who is in charge of the management of the joint venture.

"Governing law and dispute settlement issues" the second legal issues to be consider in Ethiopian commercial code to encourage JV ranked by the respondents with mean score of 3.92 .

This indicates the Joint Venture parties can choose their own choice of dispute resolution mechanisms but in the choice of forum of jurisdictions, there are some basic considerations to be made. The third legal issues to be consider in in Ethiopian legal norm is "Tax liability and accounting issues" ranked by the respondent with mean score of 3.88 .

Table 4. Rank of legal issues to be considered in Ethiopian legal norm context.

\begin{tabular}{lll}
\hline Legal Issues & Mean Score & Rank \\
\hline Duties and liability of partners & 4.01 & 1 \\
Governing law and dispute settlement issues & 3.92 & 2 \\
Tax liability and accounting issues & 3.88 & 3 \\
Legal personality & 3.84 & 4 \\
Employment and labor law issues & 3.82 & 5 \\
\hline
\end{tabular}

\subsubsection{Legal Issues to Be Consider in Commercial Code} Issues to Be Consider in Joint Venture Agreement

The respondent ranked "define the parties to the agreement" the first position to be consider in JV agreement with mean score of 4.06. Minja et al. [13] also includes define the parties to the agreement is the first issue to be consider in JV agreement. So, all JV partners should be expressed and inclusive in the JV agreement. 
The second issue to be considers in JV agreement is "define the purpose and objective of JV" ranked by the respondent with mean score of 4.04. Minja et al. [13] also agree with this research result. This indicates to prepare a well JV agreement purpose and objective of JV should be considered in agreement.

Table 5. Rank for issues to be considered in JV agreement.

\begin{tabular}{lll}
\hline Issues to be consider in JV agreement & $\begin{array}{l}\text { Mean } \\
\text { Score }\end{array}$ & Rank \\
\hline Defines the parties to the agreement & 4.06 & 1 \\
Defines the purposes and objectives of the joint venture & 4.04 & 2 \\
$\begin{array}{l}\text { Defines the basis on which the participants share in the } \\
\text { profits and losses of the joint venture }\end{array}$ & 4.03 & 3 \\
Provides for a conflict resolution mechanism & 4.01 & 4 \\
Defines the liabilities of the joint venture partners & 3.99 & 5 \\
\hline
\end{tabular}

\subsection{Appropriate Types of Construction Joint Ventures}

The dominant JV type in construction ranked by the respondent is "contractual Joint Venture" with mean score of 3.87. This indicates contractual JV type has the important factor to encourage domestic JV among local contractors. Because, the JV partners only governed by the JV agreements no specific legal rules governing this type JV.

The second dominant JV type to encourage domestic JV ranked by the respondent is "integrated JV" with mean score of 3.85. This implies integrated JV type has a strong factor to encourage domestic JV among local contractors. Because, the integrated JV can create strong and lengthy relationships between the partners and also it is the most appropriate forms of JV for mega project construction.

The respondent also ranked "private-private JV" the third position helps to encourage domestic JV with mean score of 3.84. Because, the private-private JV types helps the JV partners are relatively free to determine their rights and obligations by the joint venture agreement. So, private-private JV type should be encouraged to motivate the local contractors to make domestic JV.

Table 6. Rank of JV type.

\begin{tabular}{lll}
\hline Types of Joint Venture & Mean Score & Rank \\
\hline Contractual Joint Venture & 3.87 & 1 \\
Integrated Joint Venture & 3.85 & 2 \\
Private-Private Joint Venture & 3.84 & 3 \\
Partnership Joint Venture & 3.83 & 4 \\
Combination Joint Venture & 3.72 & 5 \\
\hline
\end{tabular}

\subsection{Risk of Construction Joint Venture}

This part consists of result and discussion of problems occurred on JV and risk factors associated with JV.

\subsubsection{Problems Occurred in Joint Venture}

Respondents participated on this research ranked "unclear partner roles" the first position to create problems in JV with mean score of 3.91. Ms. Kale, V. et al. [16] also agree with this result in this expression "a lack of clarity about how closely the two sides intend to work together is a common problem". So, to avoid problems occurs in JV the partners should be identifying their own duties and responsibility. This indicates unclear partner roles take the lion share for the problems occurred in JV.

"Misunderstanding of partnering concepts" put in the second position to create problems in JV with mean score of 3.90. This result is similar with Ms. Kale, V. et al. [16]. This indicates the partners of JV should be familiar with the concepts of JV for the success of JV. So, misunderstanding of the JV concept by the project participants could cause a failure in partnering. This implies the JV partners should be having a knowhow about a JV can provide a competitive advantage.

The third important factor create a problem in JV is "unequal sharing of risk" with mean score of 3.88. Ms. Kale, V. et al. [16] agree with this result by this expression "Ensuring an equitable risk-benefit ratio is crucial to the longer-term health of the alliance". This indicates the JV partners reach a common consensus to equally distribute risk-benefit ratio. Therefore, a fair distribution of risk and benefit can avoid a problem occurred in JV.

Table 7. Rank of factors can create a problem in JV.

\begin{tabular}{lll}
\hline Factors to create a problem in Joint Venture & Mean Score & Rank \\
\hline Unclear partner roles & 3.91 & 1 \\
Misunderstanding of partnering concept & 3.90 & 2 \\
Unequal sharing of risks and benefits & 3.88 & 3 \\
Inadequate training & 3.68 & 4 \\
The inevitable crisis & 3.65 & 5 \\
\hline
\end{tabular}

\subsubsection{Risk factors in Joint Venture}

The dominant risk factor ranked by the respondents is "partner parent company in financial problem" with mean score of 3.95. This indicates the result absolutely similar with Zirape L. et al. [21]. This implies the healthy financial statement of the partner parent company has a great factor for successful JV.

The second dominant risk factor associated with JV is "disagreement on accounting of profit and loss" with mean score of 3.91. Again, this result also absolutely the same as Zirape L. et al. [21]. This indicates fair distribution of profit and loss has an important factor for the JV partner to create a strong and lengthy alliance.

"Partners lack of management competence and resourcefulness" ranked the third important factor associated with JV with mean score of 3.85. This risk factor is also an internal risk factor as the same as the first and the second dominant risk factors. This research result indicates each party of the JV partners should be having a high degree of creativity and management competence to stay in a good partnership.

Table 8. Rank of factors associated in JV.

\begin{tabular}{lll}
\hline Risk factors associated with JV & Mean Score & Rank \\
\hline Partner's parent company in financial problem. & 3.95 & 1 \\
Disagreement on accounting of profit and loss & 3.91 & 2 \\
Partners lack of management competence and & 3.85 & 3 \\
resourcefulness. & 3.79 & 4 \\
Cash flow problem of client & 3.79 & 5 \\
Poor project relationship & \\
\hline
\end{tabular}




\section{Conclusion and Recommendation}

\subsection{Conclusion}

In this research detail assessment were made on motivation factor and reason to formation of $\mathrm{JV}$, JV partner selection factor, JV success criteria, existing legal norm about JV, and contents of JV agreement, types of JV and risk factors associated with JV. The above assessments were examined for effective way of JV formation and implementation procedure to encourage a domestic JV among local contractors.

This study can be concluded that: -

a. A technology transfer, ability, skills and experience of JV partners and JV management has an important role for local contractors to establish the effective way of JV formation and implementation procedures to participate a bid in a mega project construction.

b. No, a common consensus between a government law maker and a construction organization about the existing Ethiopian commercial code specifically from Article 272/1 up to Article 272/4 make a big controversy between government law makers and construction stake holders.

c. From the existing Ethiopian commercial code Article 272/1 and Article 272/4 enhance a discouragement between a local contractor to form an effective domestic Joint Venture due to this the local contractors has no willingness to form an effective alliance or Joint Venture to increase their competitiveness to participate a bid in a mega construction project to compare with foreign contractors.

d. Article 272/2 about legal personality of Joint Venture can discourage the local contractors to form a domestic Joint Venture. Article 272/3 about informality of JV also put little bit discouragement on local contractors to form a domestic JV.

e. To improve the application of domestic JV between local contractors the JV agreement should be define to the JV partners to eliminate the dispute between JV partners. In addition, legal issues didn't include in existing commercial code should be reconsider to include in existing Ethiopian legal norm context.

f. A contractual Joint Venture type the most preferable construction JV type to encourage and establish effective domestic JV between local contractors to participate in a mega construction project.

g. Assigning a clear and specific role and responsibility for JV partners can reduce problems appears in domestic Joint Venture. The JV partner of parent company should have adequate financial capacity to mitigate risk factors associated with Joint Venture to succeed in formed domestic Joint Venture.

In general, for the effective way of $\mathrm{JV}$ formation and for effective implementation of CJV the findings of this study indicate that the existing legal norm context about CJV should be revised with amendment of some of the articles from the existing commercial code of Ethiopia. In addition, to obtain a technology transfer between local contractors a construction
Joint Venture has an important contribution for local contractors to enhance their competitiveness in nation and worldwide.

\subsection{Recommendation}

This research has identified major shortcomings for formation of effective way of Joint Venture for local contractors in a mega project construction. Therefore, the following points are recommended to be assessed in detail, as they can be focal points for further research, to improve the JV practice among local contractor in a mega project construction: -

a. Firms entering in to the JV should be exploring the benefit and risks associated with their JV.

b. Before forming the CJV the construction organization should know about motivation factor and reason for CJV formation.

c. To ensure the existence of Joint in current Ethiopian situation the government law makers should be revise the existing Ethiopian commercial code to encourage local contractors to form effective domestic JV.

d. The Ministry of Urban Development and Construction and Ministry of Trade and Industry should reach a common consensus about JV application based on the existing commercial code and all legal norm contexts.

e. Ministry of Trade and Industry should revise all legal norms that can discourage formation of domestic JV between local contractors.

f. Ministry of Urban Development and Construction should create awareness for local contractors to form the effective domestic JV.

g. Ministry of Urban Development and Construction should give an affirmative action for the JV partnership between local contractor's firms to participate in a mega project construction.

h. The construction firms should take care about a JV partner selection before forming or entering in to domestic CJV.

i. Ministry of Trade and Industry should revise that can give unlimited liability for JV partners.

j. The construction firms should care about the forming construction JV type to succeed in formed JV.

$\mathrm{k}$. The construction organization entering in CJV should care about contents of CJV agreement.

\section{References}

[1] Aalonen, K (2008). "A network perspective on response strategies to stakeholder pressures in global projects , in miia martinsuo edt." Recipes for Success in Project-based management, 4: 29 59.

[2] Beamish, P. W. and Inkpen, A. C. (1995) "Keeping international joint ventures stable and profitable", Long Range Planning, 28 (3), 26-36.

[3] Brockmann, C. \& Brezinski, H. (2013). Contractual Joint Ventures for Megaprojects in Construction. Economics and Management of Networks Conference (EMNet) University Ibn Zohr Agadir, Morocco. 2-6. 
[4] Bryan A. Garner (ed.), "Black's Law Dictionary", (7th ed., West Group, St. Paul, Minn., 1999).

[5] Capka, J. R. (2006). Issuance of Interim Major Project Guidance. Department of Transportation Federal Highway Administration, U. S., January 27.

[6] Commercial Code Proclamation no. 166 of 1960, Negarit Gazeta, Extraordinary Issue, No. 3Addis Ababa, 1960.

[7] Deborah E. Bouchoux, "Business Organizations for Paralegals", (3rd ed., 2004, Aspen Publishers, New York), P. 161.

[8] Fiori, C., and Kovaka, M. (2005). "Defining megaprojects: learning from construction at the edge of experience." Proc. Construction Research Congress 2005, American Society of Construction Engineers.

[9] Hong, Y. and Chan, D. W. (2014). Research Trend of Joint Ventures in Construction: A Two-decade Taxonomic Review. Journal of Facilities Management (Final Accepted Manuscript). $12(2): 1-2$.

[10] Hung Hom, Kowloon, Hong Kong, China, Albert P. C. Chan Professor and Associate Dean, Faculty of Construction and Environment, The Hong Kong Polytechnic University.

[11] Inkeri Ruuskaa, Tuomas Aholaa (2011) “A new governance approach for multi-firm projects: Lessons from Olkiluoto 3 and Flamanville 3 nuclear power plant projects.” International Journal of Project Management.

[12] J. David Rogers, ASCE, 2010, Hoover Dam 75th Anniversary History Symposium.

[13] Minja, S. J., Kikwasi, G. J., and Thwala, W. D. (2012). A study of joint venture formation between construction organization in Tanzania. Australasian Journal of Construction Economics and Building. 1 (2): 1-2.

[14] Ministry of house and construction: Ethiopian construction industry development policy, Approved by ministries of house of federation, $1^{\text {st }}$ edition (Amharic version), Addis Ababa, Ethiopia, 2014.

[15] Ministry of Urban Development and Construction: Ethiopian construction industry policy, Addis Ababa, Ethiopia, 2012.

[16] Ms. Kale, V. V., Ms Patil, S. S., Ms Hiravennavar, A. R., Prof. Kamane. S. K. (2011) Joint Venture in Construction Industry. IOSR Journal of Mechanical \& Civil Engineering (IOSR-JMCE). ISSN: 2278-1684: 60-65.

[17] Samuel Asfaw, (December, 2010) "The Exploration of the Legal Framework and The Practice Relating To "Joint Ventures" In Ethiopia: A Comparative Approach", Addis Ababa University, Addis Ababa, Ethiopia.

[18] Stewart, M. R., Maughn, R. D. (2011). International Joint Ventures, A Practical Approach. Davis Wright Tremaine. LLP|877.398.841717595874-1: 1-2.

[19] Yi HU Ph. D. Student, Department of Building and Real Estate, The Hong Kong Polytechnic University.

[20] Zhiding Chen and Zhudi Sheng, Joint Venture Modes of Water Conservancy and Hydroelectric Engineering, JOURNAL OF Engineering Science and Technology 6 (2), 2013, 4952.

[21] Zirape, L. B., Warudkar, A. A. (2016). Risk Management in Construction Joint Venture Projects in Real Estate. International Journal of Engineering Science and Computing. 6 (4): 1-2 